\title{
Thoracoscopic operations in children
}

\author{
CT Lau, Jessie Leung, Theresa WC Hui, Kenneth KY Wong *
}

This article was published on 9 May 2014 at www.hkmj.org.

\section{- A video of} thoracoscopic operation is available at <www.hkmj.org>.

\section{A B S T R A C T}

Over the past two decades there has been an exponential growth in the use of thoracoscopy in children. Indeed, many advanced proceduresincluding lobectomy, repair of tracheoesophageal fistula, excision of mediastinal tumours, and diaphragmatic hernia repairs-can now be performed by this means in advanced paediatric surgical centres in the world. This review describes the historical perspectives and the current state of thoracoscopic surgery, including potential benefits and challenges, in children.

\author{
Hong Kong Med J 2014;20:234-40 \\ DOI: $10.12809 / \mathrm{hkmj} 134159$ \\ ${ }^{1}$ CT Lau, MB, BS, MRCS \\ $1 \mathrm{~J}$ Leung, MB, BS, MRCS \\ TWC Hui, MB, BS, FHKAM (Anaesthesiology) \\ KKY Wong *, FRCSEd, FHKAM (Surgery) \\ 1 Department of Surgery \\ Department of Anaesthesiology \\ LKS Faculty of Medicine, The University of Hong Kong, Pokfulam, Hong \\ Kong \\ * Corresponding author: kkywong@hku.hk
}

\section{Introduction}

Minimally invasive surgery is considered one of the most important milestones in surgery in recent decades. In this regard, operating in the thoracic cavity of children has changed drastically from an open approach to a completely thoracoscopic procedure in just a little over 30 years. In paediatric patients, thoracoscopic procedures had once been regarded as a 'state of the art' practice, but are now the standard of care for many disease conditions in advanced paediatric surgical centres. In this review, we describe their development for children and their current status.

\section{Historical perspective}

The concept of thoracoscopy was first introduced more than a hundred years ago by a Swedish physician, Hans Christian Jacobaeus. In 1910, he reported his initial experience after inserting a cystoscope into the pleural cavity to perform lysis of a tuberculous pleural adhesion as part of the treatment. But it was not until almost 70 years later in 1976, when Rodgers and Talbert ${ }^{1}$ put thoracoscopy into first practical use for paediatric patients. At this early stage, thoracoscopic procedures in children were only limited to lung biopsies, evaluation of thoracic or pulmonary lesions, and regional decortication of an empyema. ${ }^{2}$ Despite increasing recognition of its potential advantages, it did not gain widespread acceptance or popularity owing to technical and anaesthetic difficulties.

The first laparoscopic cholecystectomy in 1985 by Mühe $^{3}$ was a turning point that brought about a revolutionary change in this type of surgery. This ensuing exponential growth in the development of minimally invasive surgical procedures also stimulated the technological advances pertaining to associated surgical instruments, including the development of high-definition digital cameras, smaller-calibre instruments, and new energydelivering devices. This meant that surgeries could be performed in smaller children more safely and effectively, and in a minimally invasive manner. The experience and skills gained from laparoscopic surgeries, together with improvements in anaesthetic techniques, enabled paediatric surgeons to venture into the thoracic cavity.

\section{Advantages and difficulties}

Cosmetic superiority is the most obvious advantage provided by thoracoscopic operations (Fig 1). Smaller incisions not only meant that postoperatively there could be much smaller and almost invisible surgical scars, but more importantly the pain associated with traditional thoracotomy was greatly reduced. As a result of such extreme facility, some centres are now performing minor thoracoscopic procedures on an out-patient basis. ${ }^{4}$ In addition, the significant decrease in overall wound lengths and tension reduced the risks of wound infection and dehiscence, ${ }^{5}$ which were associated with shorter hospital stays and earlier recovery. ${ }^{6,7}$

The most dreaded and well-known long-term complications of thoracotomy are musculoskeletal. They include chest wall deformities, rib fusion, shoulder girdle weakness and scoliosis, and can occur in up to $30 \%$ of patients undergoing thoracotomy. ${ }^{8,9}$ The mechanism underlying these problems is related to the division of shoulder girdle muscles such as the latissimus and serratus, and often resulted in girdle weakness. Furthermore, the tensile forces created by thoracotomy wound closure over the ipsilateral 
chest wall could distort the thoracic cage as the child grows. ${ }^{10}$ In contrast, these complications are virtually non-existent in patients who undergo thoracoscopic procedures. ${ }^{11}$

Thoracoscopic operations enable surgeons to enjoy superior surgical visibility and precision. With the aid of high-definition monitors and cameras, the smallest structures including blood vessels and nerves can now be visualised under magnification (Fig 2), which allowed surgeons to dissect with greater precision and thus avoid unintentional injuries. Another advantage of thoracoscopy is provided by telescopes with viewing angles that enable easy evaluation of the whole thoracic cavity and the entire lung surface from a limited port access. As a result, even the most deep-seated areas and corners can now be seen clearly, which was previously not possible during conventional thoracotomies.

Everything comes at a price, and thoracoscopic surgery is no exception. First, there are the challenges encountered across the spectrum of minimally invasive surgery in general, and include lack of three-dimensional vision, reduced feedback from tactile sensation, and the protracted learning curve for paediatric thoracoscopic surgeons. One reason for the latter was the body size of our patients. Since a young child with only half the height of an adult provides one-eighth the working thoracoscopic space, the difficulties encountered in manipulating instruments inside the thorax of a neonate are obvious. Second, apart from the limitation of working space (always a concern for paediatric surgeons), the ability to achieve adequate single-lung ventilation was also a limitation. This was partially solved by creating more space, as well as the development of smaller instruments that allowed finer and more ergonomically friendly movements. Third, the variation in body size among paediatric patients also made the learning process difficult. Surgeons had to adapt from a 3-kg neonate to a 70-kg teenager, before they could truly master all the necessary skills, which also imposed a significant effect on the length of the learning curve.

Safe control of major vasculature and other passages remains a major challenge even for experienced surgeons, especially in the case of thoracoscopic lobectomy. Unlike adults, in whom the endoscopic stapler can be employed to take control of the pulmonary vessels and bronchi, this device often proves too large to be used in children, as a 12-mm trocar port and at least $5 \mathrm{~cm}$ of intrathoracic space are required for it to open fully. ${ }^{12} \mathrm{New}$ sealing devices-such as LigaSure (Covidien, US), EnSeal (Ethicon, US), and Thunderbeat (Olympus, Japan)allow safe sealing of the main pulmonary vessels up to $7 \mathrm{~mm}$ in diameter and thus they have replaced resorting to endoclips, which may dislodge during dissection or obscure satisfactory tissue dissection

\section{兒童胸腔鏡手術的應用 \\ 劉展軕、梁凌、許韻璇、黃格元}

在過去二十年，胸腔鏡在小兒外科手術中的使用與日漸增。事實上， 在世界各地一些先進的小兒外科中心內已經可以利用胸腔鏡進行很多 較為困難和複雜的手術, 包括肺葉切除術、縱隔腫瘤切除術、修復氣 管食管瘺和膈疝修復。本文簡述胸腔鏡應用在小兒外科手術的歷史及 現況, 並討論其潛在優點和所面對的挑戰。

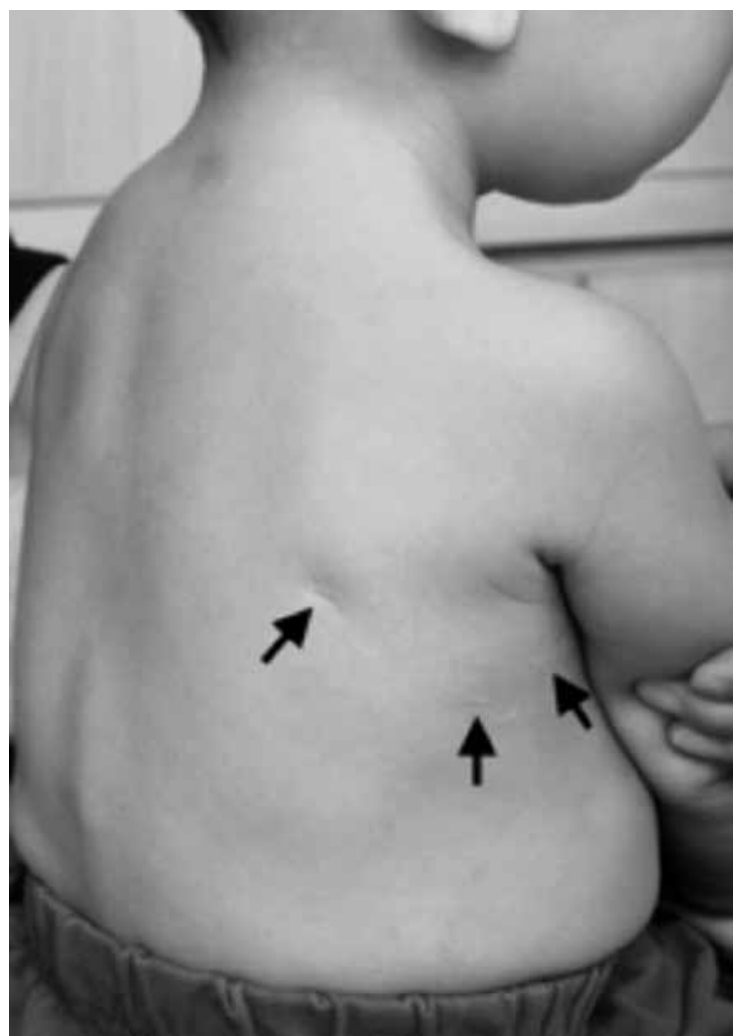

FIG I. A clinical photograph of a child after thoracoscopic operation with minimal scars (arrows)

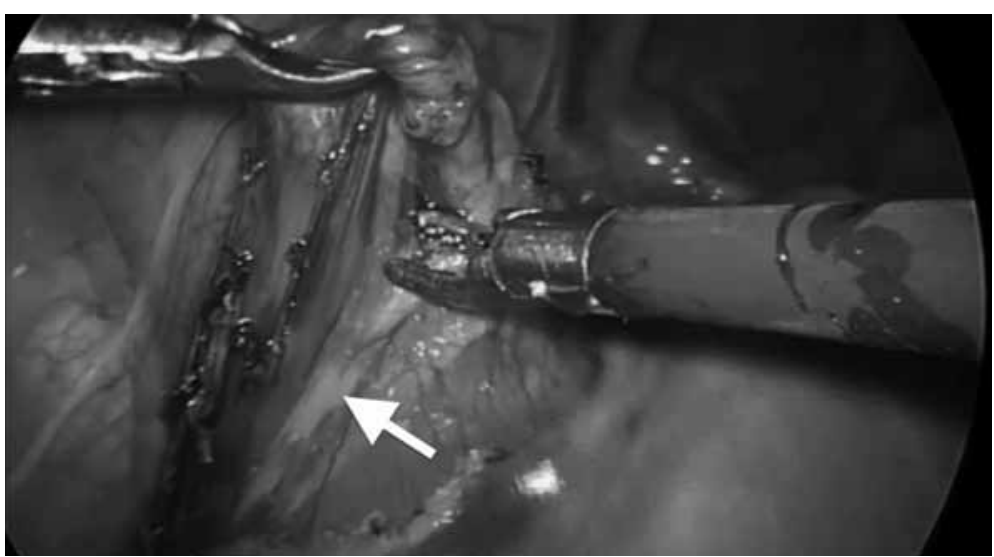

FIG 2. An intra-operative photograph during thoracoscopic excision of oesophageal duplication cyst. This shows an excellent view of the vagus nerve (arrow) 
due to the space they occupy. These energy-sealing devices also diminish technical difficulties during the performance of complex lobectomies, as they are proven to be safe and efficient in sealing off lung tissues and dividing incomplete fissures. ${ }^{13}$ Nonetheless, a complete understanding of the threedimensional anatomical relationships and precision in tissue dissection is still the key to success.

\section{Anaesthetic aspects}

Paediatric thoracoscopic surgery is not only about surgical and technical refinements. Anaesthetic techniques play a major role in achieving successful thoracoscopic surgery. To create adequate thoracic space for efficient surgery with good exposure, single-lung ventilation is a prerequisite in the surgical management of many thoracic conditions. Unlike adults in whom single-lung ventilation can be easily performed using a double-lumen endotracheal tube, this is not feasible in young children. The smallest double lumen tube is a $26 \mathrm{~F}$, and may even be used for children younger than 8 years old. For even smaller patients, standard

TABLE I. Conditions with thoracoscopic procedures reported in the literature

\begin{tabular}{ll}
\hline Condition & Thoracoscopic procedure \\
\hline Achalasia & Cardiomyotomy \\
\hline Bronchogenic cyst & Excision \\
\hline Bronchopulmonary sequestration & Resection \\
\hline Chylothorax & Thoracic duct ligation \\
\hline Congenital cystic adenomatoid malformation & Lobectomy \\
\hline Diaphragmatic eventration & Diaphragmatic plication \\
\hline Diaphragmatic hernia & Hernia repair \\
\hline Diaphragmatic rupture & Diaphragmatic repair \\
\hline Empyema & Decortication \\
\hline Lobar emphysema & Lobectomy \\
\hline Lung tumour & Biopsy $+/-$ excision \\
\hline Mediastinal tumour & Biopsy $+/-$ excision \\
\hline Myasthenia gravis & Thymectomy \\
\hline Oesophageal atresia $+/-$ trachea-oesophageal fistula & Repair $+/-$ closure of fistula \\
\hline Oesophageal diverticulum & Excision \\
\hline Oesophageal duplication cyst & Excision \\
\hline Oesophageal stenosis & Oesophagectomy $+/-$ \\
& conduit reconstruction \\
\hline Palmar hyperhidrosis & Sympathectomy \\
\hline Patent ductus arteriosus & Ligation \\
\hline Pectus excavatum & Nuss procedure \\
\hline Pericardial cyst & Excision \\
\hline Pericardial effusion & Pericardial fenestration \\
\hline Pneumothorax & Pleurodesis $+/-$ bullectomy \\
\hline Spine deformity & Anterior spinal fusion \\
\hline & Aortopexy \\
\hline Tracheomalacia & \\
\hline
\end{tabular}

endotracheal intubation together with insertion of an endobronchial blocker in the ipsilateral bronchus of the operated lung or selective intubation of the contralateral bronchus with an endotracheal tube turn out to be the solution. An endobronchial blocker is a catheter-like device with a balloon attached to its tip for occlusion and contains a central stylet. Depending on the size of the patient, under fibreoptic bronchoscopic guidance, the endobronchial blocker is placed either within or outside the lumen of the endotracheal tube and advanced into the main stem bronchus of choice. The balloon is then inflated to create bronchial occlusion under direct vision. Problems with bronchial blockers include dislodgement of the blocker balloon into the trachea with blockade of ventilation, and overdistention of the balloon leading to damage of the airway. With selective intubation of the contralateral main stem bronchus, an uncuffed endotracheal tube around half to one size smaller than the usual is selected for advancement into the main stem bronchus under fibre-optic bronchoscopic guidance. Problems with selective main stem intubation include difficulty providing adequate seal, obstruction of the upper lobe bronchus, and inability to provide suction for the operative lung. ${ }^{4}$ Both of these techniques have produced single-lung ventilation with satisfactory result. ${ }^{14}$

After successful establishment of single-lung ventilation, lung collapse can be enhanced further by carbon dioxide insufflation into the thorax. This is particularly helpful in the event the endobronchial tube is not totally occlusive resulting in a degree of overflow ventilation. Carbon dioxide infusion at low pressure $(4 \mathrm{~mm} \mathrm{Hg})$ and low flow $(1 \mathrm{~L} / \mathrm{min})$ helps keep the lung compressed during the surgery and reduces the risk of injury from using a retractor. Maintenance of this low-setting environment requires the use of valved trocars.

The safety of single-lung ventilation in paediatric patients had been a major concern. Although there was a previous report on mucosal or bronchial injury during intubation, ${ }^{14}$ several recently reported large series ${ }^{15-17}$ have demonstrated the safety and efficacy of single-lung ventilation in children, without major complications or mortality. Dingemann et $\mathrm{al}^{18}$ compared children having singlelung ventilation and those having conventional two-lung ventilation. They found no statistically significant difference between the groups in terms of the timing of extubation, the rate of postoperative atelectasis or pneumonia, and the length of intensive care unit stays.

Increased compression of the dependent lung in the lateral decubitus position, surgical retraction and single-lung ventilation with collapse of the operative lung can aggravate ventilation-perfusion mismatch. Intra-operative hypercapnia and acidosis 
TABLE 2. Summary of major studies on selected thoracoscopic procedures ${ }^{7}, 18,20,21,24,27-29,31-70$

\begin{tabular}{|c|c|c|c|c|c|}
\hline Disease group & Author(s) & Year & Study design & Study type & $\begin{array}{l}\text { No. of thoracoscopic } \\
\text { procedures }\end{array}$ \\
\hline \multirow[t]{9}{*}{ Empyema } & Aziz et $\left.a\right|^{31}$ & 2008 & Retrospective & Case control & 28 \\
\hline & Chiu et $\mathrm{a}^{32}$ & 2006 & Retrospective & Case control & 11 \\
\hline & Freitas et $\mathrm{al}^{33}$ & 2009 & Retrospective & Case series & 99 \\
\hline & Gates et $\mathrm{al}^{34}$ & 2004 & Retrospective & Case control & Not mentioned \\
\hline & Kurt et al ${ }^{35}$ & 2006 & Prospective & Randomised trial & 10 \\
\hline & Padman et $\mathrm{al}^{36}$ & 2007 & Retrospective & Case control & 50 \\
\hline & St Peter et $\mathrm{al}^{37}$ & 2009 & Prospective & Randomised trial & 18 \\
\hline & Tsao et $\mathrm{al}^{38}$ & 2008 & Retrospective & Case series & 79 \\
\hline & Wong et $\mathrm{a}^{39}$ & 2005 & Retrospective & Case control & 49 \\
\hline \multirow[t]{5}{*}{ Pneumothorax with lung bulla } & Bialas et $\mathrm{al}^{40}$ & 2008 & Retrospective & Case series & 41 \\
\hline & Choi et al ${ }^{41}$ & 2013 & Retrospective & Case series & 126 \\
\hline & Chung et $\mathrm{a}^{24}$ & 2009 & Retrospective & Case series & 15 \\
\hline & Ozcan et al ${ }^{42}$ & 2003 & Retrospective & Case series & 32 \\
\hline & Qureshi et $\mathrm{al}^{43}$ & 2005 & Retrospective & Case control & 34 \\
\hline \multirow[t]{9}{*}{ Congenital lung lesions } & Bonnard et al ${ }^{44}$ & 2004 & Retrospective & Case control & 3 \\
\hline & Bratu et $\mathrm{al}^{45}$ & 2005 & Retrospective & Case control & 11 \\
\hline & Diamond et al ${ }^{46}$ & 2007 & Retrospective & Case control & 12 \\
\hline & Kunisaki et al ${ }^{47}$ & 2014 & $\begin{array}{l}\text { Retrospective/ } \\
\text { prospective }\end{array}$ & Cohort & 49 \\
\hline & Lau et $\mathrm{al}^{7}$ & 2013 & Retrospective & Case control & 39 \\
\hline & Rahman and Lakhoo 48 & 2009 & Retrospective & Case control & 14 \\
\hline & Rothenberg et $\mathrm{al}^{49}$ & 2011 & Retrospective & Case series & 75 \\
\hline & Tölg et al $\left.\right|^{50}$ & 2005 & Retrospective & Case control & 4 \\
\hline & Vu et al ${ }^{51}$ & 2008 & Retrospective & Case control & 12 \\
\hline \multirow{11}{*}{$\begin{array}{l}\text { Oesophageal atresia }+/- \\
\text { trachea-oesophageal fistula }\end{array}$} & Al Tokhais et al ${ }^{52}$ & 2008 & Retrospective & Case control & 23 \\
\hline & Allal et $\mathrm{a}^{28}$ & 2009 & Retrospective & Case control & 14 \\
\hline & Dingemann et $\mathrm{al}^{18}$ & 2013 & Retrospective & Case control & 22 \\
\hline & Holcomb et $a^{53}$ & 2005 & Retrospective & Case series & 104 \\
\hline & Huang et $\mathrm{al}^{29}$ & 2012 & Retrospective & Case series & 33 \\
\hline & Lugo et al ${ }^{54}$ & 2008 & Retrospective & Case control & 8 \\
\hline & MacKinlay ${ }^{55}$ & 2009 & Retrospective & Case series & 26 \\
\hline & Nguyen et al ${ }^{56}$ & 2006 & Retrospective & Case series & 6 \\
\hline & Rothenberg ${ }^{57}$ & 2013 & Retrospective & Case series & 52 \\
\hline & Szavay et $\mathrm{al}^{27}$ & 2011 & Retrospective & Case control & 25 \\
\hline & van der Zee et al $\left.\right|^{58}$ & 2012 & Retrospective & Case series & 72 \\
\hline \multirow[t]{14}{*}{ Congenital diaphragmatic hernia } & Arca et al ${ }^{59}$ & 2003 & Retrospective & Case series & 7 \\
\hline & Becmeur et al ${ }^{60}$ & 2007 & Retrospective & Case series & 14 \\
\hline & Cho et al ${ }^{61}$ & 2009 & Retrospective & Case control & 29 \\
\hline & Fishman et $\mathrm{al}^{20}$ & 2011 & Retrospective/prospective & Cohort & 12 \\
\hline & Gander et $a^{62}$ & 2011 & Retrospective & Case control & 35 \\
\hline & Gomes Ferreira et $a^{63}$ & 2009 & Retrospective & Case series & 18 \\
\hline & Gourlay et al ${ }^{64}$ & 2009 & Retrospective & Cohort & 20 \\
\hline & Keijzer et al 65 & 2010 & Retrospective & Case control & 23 \\
\hline & Kim et $\mathrm{al}^{66}$ & 2009 & Retrospective & Case series & 15 \\
\hline & Lao et $\mathrm{al}^{67}$ & 2010 & Retrospective & Case control & 14 \\
\hline & McHoney et $\mathrm{a}^{21}$ & 2010 & Retrospective & Case control & 13 \\
\hline & Okazaki et al ${ }^{68}$ & 2011 & Prospective & Cohort & 8 \\
\hline & Szavay et al ${ }^{69}$ & 2012 & Retrospective & Case control & 17 \\
\hline & Yang et $\mathrm{al}^{70}$ & 2005 & Retrospective & Case series & 7 \\
\hline
\end{tabular}


associated with thoracoscopic procedures have been well documented. ${ }^{19-21}$ It has been postulated that hypercapnia and acidosis are caused by the use of carbon dioxide as the insufflation agent, increasing carbon dioxide absorption into the systemic circulation. Based on a pilot randomised controlled trial, Bishay et $\mathrm{a}^{22}$ has confirmed the presence of prolonged hypercapnia in thoracoscopic surgery patients compared to those having open thoracotomy, but the long-term consequence of this finding was unclear.

\section{Selected conditions}

Thus far, thoracoscopy has been reported to be the surgical approach in more than 20 types of thoracic conditions in children and infants (Table 1). As there are neither absolute contra-indication nor guidelines on which thoracic condition should or should not be performed thoracoscopically, this means that virtually all chest condition can be managed in this manner.

Thoracic empyema was the first condition in which the thoracoscopic approach was deployed. Early thoracoscopic decortication following the failure of initial conservative treatment with chest tube drainage and antibiotics is now recommended. ${ }^{23}$ In most patients, primary spontaneous pneumothorax has been shown to be related to underlying lung bullae. ${ }^{24}$ These can be managed by thoracoscopic bullectomy without the need for prolonged chest tube drainage and hospitalisation, which is in contrast to simple conservative management. Moreover, it has evolved to become the standard treatment in many regional centres. Likewise, thoracoscopic lung biopsy has been widely used as a diagnostic tool in interstitial lung disease or for intrathoracic tumour, and some centres even advocate these to be performed as daycase procedures..$^{25}$

The most commonly performed thoracoscopic operation in young infants is for congenital cystic lung disease. The condition consists of congenital cystic adenomatoid malformations, bronchopulmonary sequestration, bronchogenic cysts, and congenital lobar emphysemas. With the increasing use of antenatal ultrasonography during routine follow-up, there has been a significant increase in the reported incidence of this disease. Thoracoscopic resection or lobectomy is usually recommended at 6 months of age, in view of the risks from frequent pneumonia and the potential for future malignancies.

Centres with experience have now pushed the application of paediatric thoracoscopic surgery towards the treatment of neonatal conditions. Ever since the first successful case of thoracoscopic repair of oesophageal atresia in 1999, ${ }^{26}$ the procedure has been labelled as the 'pinnacle of paediatric surgery'. Due to its difficulty, only a few small series (including ours) have been published and the initial results are encouraging. ${ }^{27-29}$ Repair of Bochdalek's congenital diaphragmatic hernia is also routinely managed using the thoracoscopic approach. Due to the underlying pulmonary hypoplasia, the thoracic cavity on the affected side provides excellent working space, for which single-lung ventilation may not be necessary and only very-low-pressure low-flow carbon dioxide insufflation is all that is required. ${ }^{30}$ Table $2^{7,18,20,21,24,27-}$ 29,31-70 provides a brief summary of the major studies dealing with the aforementioned conditions.

\section{Conclusion}

Thoracoscopic surgery in children has come a long way since its inception. There is solid evidence supporting its safety and applicability in routine clinical use. More prospective studies are required to determine whether it offers genuine advantages over traditional open surgery.

\section{References}

1. Rodgers BM, Talbert JL. Thoracoscopy for diagnosis of intrathoracic lesions in children. J Pediatr Surg 1976;11:703-8.

2. Rodgers BM. Pediatric thoracoscopy: where have we come and what have we learned? Ann Thorac Surg 1993;56:7047.

3. Mühe E. Laparoscopic cholecystectomy-late results [in German]. Langenbecks Arch Chir Suppl Kongressbd 1991:416-23.

4. Rothenberg SS. Thoracoscopic pulmonary surgery. Semin Pediatr Surg 2007;16:231-7.

5. Blinman T. Incisions do not simply sum. Surg Endosc 2010;24:1746-51.

6. Nasr A, Bass J. Thoracoscopic vs open resection of congenital lung lesions: a meta-analysis. J Pediatr Surg 2012;47:857-61.

7. Lau CT, Leung L, Chan $\mathrm{IH}$, et al. Thoracoscopic resection of congenital cystic lung lesions is associated with better post-operative outcomes. Pediatr Surg Int 2013;29:341-5.

8. Jaureguizar E, Vazquez J, Murcia J, Diez Pardo JA. Morbid musculoskeletal sequelae of thoracotomy for tracheoesophageal fistula. J Pediatr Surg 1985;20:511-4.

9. Korovessis P, Papanastasiou D, Dimas A, Karayannis A. Scoliosis by acquired rib fusion after thoracotomy in infancy. Eur Spine J 1993;2:53-5.

10. Blinman T, Ponsky T. Pediatric minimally invasive surgery: laparoscopy and thoracoscopy in infants and children. Pediatrics 2012;130:539-49.

11. Lawal TA, Gosemann JH, Kuebler JF, Glüer S, Ure BM. Thoracoscopy versus thoracotomy improves midterm musculoskeletal status and cosmesis in infants and children. Ann Thorac Surg 2009;87:224-8.

12. Rothenberg SS. First decade's experience with thoracoscopic lobectomy in infants and children. J Pediatr Surg 2008;43:40-4; discussion 45.

13. Bignon H, Buela E, Martinez-Ferro M. Which is the best vessel-sealing method for pediatric thoracoscopic lobectomy? J Laparoendosc Adv Surg Tech A 2010;20:3958.

14. Ender J, Brodowsky M, Falk V, et al. High-frequency 
jet ventilation as an alternative method compared to conventional one-lung ventilation using double-lumen tubes during minimally invasive coronary artery bypass graft surgery. J Cardiothorac Vasc Anesth 2010;24:602-7.

15. Bataineh ZA, Zoeller C, Dingemann C, Osthaus A, Suempelmann R, Ure B. Our experience with single lung ventilation in thoracoscopic paediatric surgery. Eur J Pediatr Surg 2012;22:17-20.

16. Gentili A, Lima M, De Rose R, Pigna A, Codeluppi V, Baroncini S. Thoracoscopy in children: anaesthesiological implications and case reports. Minerva Anestesiol 2007;73:161-71.

17. Byon HJ, Lee JW, Kim JK, et al. Anesthetic management of video-assisted thoracoscopic surgery (VATS) in pediatric patients: the issue of safety in infant and younger children. Korean J Anesthesiol 2010;59:99-103.

18. Dingemann C, Zoeller C, Ure B. Thoracoscopic repair of oesophageal atresia: results of a selective approach. Eur J Pediatr Surg 2013;23:14-8.

19. Bliss D, Matar M, Krishnaswami S. Should intraoperative hypercapnea or hypercarbia raise concern in neonates undergoing thoracoscopic repair of diaphragmatic hernia of Bochdalek? J Laparoendosc Adv Surg Tech A 2009;19 Suppl 1:S55-8.

20. Fishman JR, Blackburn SC, Jones NJ, et al. Does thoracoscopic congenital diaphragmatic hernia repair cause a significant intraoperative acidosis when compared to an open abdominal approach? J Pediatr Surg 2011;46:45861.

21. McHoney M, Giacomello L, Nah SA, et al. Thoracoscopic repair of congenital diaphragmatic hernia: intraoperative ventilation and recurrence. J Pediatr Surg 2010;45:355-9.

22. Bishay M, Giacomello L, Retrosi G, et al. Hypercapnia and acidosis during open and thoracoscopic repair of congenital diaphragmatic hernia and esophageal atresia: results of a pilot randomized controlled trial. Ann Surg 2013;258:895-900.

23. Islam S, Calkins CM, Goldin AB, et al. The diagnosis and management of empyema in children: a comprehensive review from the APSA Outcomes and Clinical Trials Committee. J Pediatr Surg 2012;47:2101-10.

24. Chung PH, Wong KK, Lan LC, Tam PK. Thoracoscopic bullectomy for primary spontaneous pneumothorax in pediatric patients. Pediatr Surg Int 2009;25:763-6.

25. Rothenberg SS, Wagner JS, Chang JH, Fan LL. The safety and efficacy of thoracoscopic lung biopsy for diagnosis and treatment in infants and children. J Pediatr Surg 1996;31:100-3; discussion 103-4.

26. Rothenberg SS. Thoracoscopic repair of tracheoesophageal fistula in newborns. J Pediatr Surg 2002;37:869-72.

27. Szavay PO, Zundel S, Blumenstock G, et al. Perioperative outcome of patients with esophageal atresia and tracheoesophageal fistula undergoing open versus thoracoscopic surgery. J Laparoendosc Adv Surg Tech A 2011;21:439-43.

28. Allal H, Pérez-Bertólez S, Maillet O, et al. Comparative study of thoracoscopy versus thoracotomy in esophageal atresia [in Spanish]. Cir Pediatr 2009;22:177-80.

29. Huang J, Tao J, Chen K, et al. Thoracoscopic repair of oesophageal atresia: experience of 33 patients from two tertiary referral centres. J Pediatr Surg 2012;47:2224-7.

30. Lansdale N, Alam S, Losty PD, Jesudason EC. Neonatal endosurgical congenital diaphragmatic hernia repair: a systematic review and meta-analysis. Ann Surg 2010;252:20-6.
31. Aziz A, Healey JM, Qureshi F, et al. Comparative analysis of chest tube thoracostomy and video-assisted thoracoscopic surgery in empyema and parapneumonic effusion associated with pneumonia in children. Surg Infect (Larchmt) 2008;9:317-23.

32. Chiu CY, Wong KS, Huang YC, Lai SH, Lin TY. Echoguided management of complicated parapneumonic effusion in children. Pediatr Pulmonol 2006;41:1226-32.

33. Freitas S, Fraga JC, Canani F. Thoracoscopy in children with complicated parapneumonic pleural effusion at the fibrinopurulent stage: a multi-institutional study [in English, Portuguese]. J Bras Pneumol 2009;35:660-8.

34. Gates RL, Hogan M, Weinstein S, Arca MJ. Drainage, fibrinolytics, or surgery: a comparison of treatment options in pediatric empyema. J Pediatr Surg 2004;39:1638-42.

35. Kurt BA, Winterhalter KM, Connors RH, Betz BW, Winters JW. Therapy of parapneumonic effusions in children: video-assisted thoracoscopic surgery versus conventional thoracostomy drainage. Pediatrics 2006;118:e547-53.

36. Padman R, King KA, Iqbal S, Wolfson PJ. Parapneumonic effusion and empyema in children: retrospective review of the duPont experience. Clin Pediatr (Phila) 2007;46:51822.

37. St Peter SD, Tsao K, Spilde TL, et al. Thoracoscopic decortication vs tube thoracostomy with fibrinolysis for empyema in children: a prospective, randomized trial. J Pediatr Surg 2009;44:106-11; discussion 111.

38. Tsao K, St Peter SD, Sharp SW, et al. Current application of thoracoscopy in children. J Laparoendosc Adv Surg Tech A 2008;18:131-5.

39. Wong KS, Lin TY, Huang YC, Chang LY, Lai SH. Scoring system for empyema thoracis and help in management. Indian J Pediatr 2005;72:1025-8.

40. Bialas RC, Weiner TM, Phillips JD. Video-assisted thoracic surgery for primary spontaneous pneumothorax in children: is there an optimal technique? J Pediatr Surg 2008;43:2151-5.

41. Choi SY, Kim YH, Jo KH, et al. Video-assisted thoracoscopic surgery for primary spontaneous pneumothorax in children. Pediatr Surg Int 2013;29:505-9.

42. Ozcan C, McGahren ED, Rodgers BM. Thoracoscopic treatment of spontaneous pneumothorax in children. J Pediatr Surg 2003;38:1459-64.

43. Qureshi FG, Sandulache VC, Richardson W, Ergun O, Ford HR, Hackam DJ. Primary vs delayed surgery for spontaneous pneumothorax in children: which is better? J Pediatr Surg 2005;40:166-9.

44. Bonnard A, Malbezin S, Ferkdadji L, Luton D, Aigrain Y, de Lagauise P. Pulmonary sequestration children: is the thoracoscopic approach a good option? Surg Endosc 2004;18:1364-7.

45. Bratu I, Laberge JM, Flageole H, Bouchard S. Foregut duplications: is there an advantage to thoracoscopic resection? J Pediatr Surg 2005;40:138-41.

46. Diamond IR, Herrera P, Langer JC, Kim PC. Thoracoscopic versus open resection of congenital lung lesions: a casematched study. J Pediatr Surg 2007;42:1057-61.

47. Kunisaki SM, Powelson IA, Haydar B, et al. Thoracoscopic vs open lobectomy in infants and young children with congenital lung malformations. J Am Coll Surg 2014;218:261-70.

48. Rahman N, Lakhoo K. Comparison between open and thoracoscopic resection of congenital lung lesions. J Pediatr Surg 2009;44:333-6. 
49. Rothenberg SS, Kuenzler KA, Middlesworth W, et al. Thoracoscopic lobectomy in infants less than $10 \mathrm{~kg}$ with prenatally diagnosed cystic lung disease. J Laparoendosc Adv Surg Tech A 2011;21:181-4.

50. Tölg C, Abelin K, Laudenbach V, et al. Open vs thoracoscopic surgical management of bronchogenic cysts. Surg Endosc 2005;19:77-80.

51. Vu LT, Farmer DL, Nobuhara KK, Miniati D, Lee H. Thoracoscopic versus open resection for congenital cystic adenomatoid malformations of the lung. J Pediatr Surg 2008;43:35-9

52. Al Tokhais T, Zamakhshary M, Aldekhayel S, et al. Thoracoscopic repair of tracheoesophageal fistulas: a casecontrol matched study. J Pediatr Surg 2008;43:805-9.

53. Holcomb GW 3rd, Rothenberg SS, Bax KM, et al. Thoracoscopic repair of esophageal atresia and tracheoesophageal fistula: a multi-institutional analysis. Ann Surg 2005;242:422-8; discussion 428-30.

54. Lugo B, Malhotra A, Guner Y, Nguyen T, Ford H, Nguyen NX. Thoracoscopic versus open repair of tracheoesophageal fistula and esophageal atresia. J Laparoendosc Adv Surg Tech A 2008;18:753-6.

55. MacKinlay GA. Esophageal atresia surgery in the 21st century. Semin Pediatr Surg 2009;18:20-2.

56. Nguyen T, Zainabadi K, Bui T, Emil S, Gelfand D, Nguyen $\mathrm{N}$. Thoracoscopic repair of esophageal atresia and tracheoesophageal fistula: lessons learned. J Laparoendosc Adv Surg Tech A 2006;16:174-8.

57. Rothenberg SS. Thoracoscopic repair of esophageal atresia and tracheoesophageal fistula in neonates, first decade's experience. Dis Esophagus 2013;26:359-64.

58. van der Zee DC, Tytgat SH, Zwaveling S, van Herwaarden MY, Vieira-Travassos D. Learning curve of thoracoscopic repair of esophageal atresia. World J Surg 2012;36:2093-7.

59. Arca MJ, Barnhart DC, Lelli JL Jr, et al. Early experience with minimally invasive repair of congenital diaphragmatic hernias: results and lessons learned. J Pediatr Surg 2003;38:1563-8.

60. Becmeur F, Reinberg O, Dimitriu C, Moog R, Philippe P. Thoracoscopic repair of congenital diaphragmatic hernia in children. Semin Pediatr Surg 2007;16:238-44.
61. Cho SD, Krishnaswami S, Mckee JC, Zallen G, Silen ML, Bliss DW. Analysis of 29 consecutive thoracoscopic repairs of congenital diaphragmatic hernia in neonates compared to historical controls. J Pediatr Surg 2009;44:806; discussion 86

62. Gander JW, Fisher JC, Gross ER, et al. Early recurrence of congenital diaphragmatic hernia is higher after thoracoscopic than open repair: a single institutional study. J Pediatr Surg 2011;46:1303-8.

63. Gomes Ferreira C, Reinberg O, Becmeur F, et al. Neonatal minimally invasive surgery for congenital diaphragmatic hernias: a multicenter study using thoracoscopy or laparoscopy. Surg Endosc 2009;23:1650-9.

64. Gourlay DM, Cassidy LD, Sato TT, Lal DR, Arca MJ. Beyond feasibility: a comparison of newborns undergoing thoracoscopic and open repair of congenital diaphragmatic hernias. J Pediatr Surg 2009;44:1702-7.

65. Keijzer R, van de Ven C, Vlot J, et al. Thoracoscopic repair in congenital diaphragmatic hernia: patching is safe and reduces the recurrence rate. J Pediatr Surg 2010;45:9537.

66. Kim AC, Bryner BS, Akay B, Geiger JD, Hirschl RB, Mychaliska GB. Thoracoscopic repair of congenital diaphragmatic hernia in neonates: lessons learned. J Laparoendosc Adv Surg Tech A 2009;19:575-80.

67. Lao OB, Crouthamel MR, Goldin AB, Sawin RS, Waldhausen JH, Kim SS. Thoracoscopic repair of congenital diaphragmatic hernia in infancy. J Laparoendosc Adv Surg Tech A 2010;20:271-6.

68. Okazaki T, Nishimura K, Takahashi T, et al. Indications for thoracoscopic repair of congenital diaphragmatic hernia in neonates. Pediatr Surg Int 2011;27:35-8.

69. Szavay PO, Obermayr F, Maas C, Luenig H, Blumenstock G, Fuchs J. Perioperative outcome of patients with congenital diaphragmatic hernia undergoing open versus minimally invasive surgery. J Laparoendosc Adv Surg Tech A 2012;22:285-9.

70. Yang EY, Allmendinger N, Johnson SM, Chen C, Wilson JM, Fishman SJ. Neonatal thoracoscopic repair of congenital diaphragmatic hernia: selection criteria for successful outcome. J Pediatr Surg 2005;40:1369-75. 